\title{
The Factor Analysis of Marketing Mix for Coffee Franchise (Case Study: Bengras Kopi)
}

\author{
Rini Sarianti ${ }^{1}$, Dabitha Wise Maliha ${ }^{2}$, Harimukti Wandebori ${ }^{3}$ \\ 1 Institut Teknologi Bandung, Bandung, Indonesia, $\bowtie$ dabitha.wise@sbm-itb.ac.id \\ 2 Universitas Negeri Padang, Padang, Indonesia, $\square$ rini_sarianti@yahoo.com \\ 3 Institut Teknologi Bandung, Bandung, Indonesia, $\square$ harimukti@sbm-itb.ac.id
}

\begin{abstract}
This research aims to help Bengras Kopi's team to improve their franchise system through the marketing mix. To identify the problems, this research uses factor analysis to summarize the variables related to the customer's perception and expectation. This research uses quantitative methods based on accidental sampling for collecting data from questionnaires. The total respondents are 113 people who consider as the customers of Bengras Kopi's branches in Bandung and Padang. Based on this analysis, this research finds product, price, place, and promotion are the main factors to develop a marketing strategy based on customer's perspective for Bengras Kopi. In conclusion, these variables can be used as score measurement for indicators in the marketing plan.
\end{abstract}

Keywords: Coffee Shop, Franchise, Marketing Mix

\section{Introduction}

Nowadays, the coffee shop is one of the most important global retail beverage market, especially in Indonesia. This country dominates the global retail coffee market and keeps increases with an average sales growth of 19.6 percent each year throughout the last five years, followed by India (15.1 percent average growth) and Vietnam (14.9 percent average growth) in second and third position (Tempo, 2017). Furthermore, this country is the fourth largest coffee producers in the world which produced

11.1 million bags (BBC, 2018). The domestic coffee consumption also keeps growing every year from 3.333 million bags in 2011, 4.167 million bags in 2014, to 4.600 million bags in 2017 (Indonesia Investments, 2017). Thus, these potentials can lead coffee shops to keep growing and expanding market every year.

However, the increasing number of coffee shops can lead to fierce competition, including small business local shops and global retail chains. Most of the local coffee shops are still low-rank comparing with the western coffee shop like Starbucks. This brand successfully gives influence to Americanised coffee tradition globally and focus on upper-middle class customers. Therefore, as one of the local coffee shop, Bengras Kopi tries to promote Indonesian coffee as local wisdom with the middle-lower class as their segmentation.

Bengras Kopi is a Sundanese small business coffee shop founded in 2013. This company sells robusta coffee with affordable price and good quality. At first, Bengras Kopi were fully managed by a Co-Founder, Mr. Erwin Budiman. To develop his business, Bengras Kopi uses a franchise system as an alternative to expanding branches. Mr. Erwin started cooperated with the franchisee for opening new branches. On September 2013, Bengras Kopi was officially opened a new branch in Garut. Then, it followed by Bengras Kopi Padang on November 2013. On February 2014, Mr. Erwin made cooperated with his friend and started a new branch in Cipadung. Then, at the early of 2015, Bengras Kopi opened 
A new franchisee branch in the front of Widyatama University, Cikutra. At the same year, Bengras Kopi opened a new branch in Sukapura, Dago, Jatinangor, and Cimahi. However, the franchise system did not go well. During 2014 - 2015, Bengras Kopi faced many obstacles and challenges to manage the branches.

Most of franchisee branches did not able to sustain their business. Bengras Kopi Sukapura and Sukabirus closed in 2015. At the same year, Bengras Kopi Cikutra also closed and it is only existed for 3 months. It also followed by a new branch in Dago. This branch only existed for 6 months. Then, Bengras Kopi Jatinangor only existed during 3 months. Followed by Cimahi branch only existed for 8 months. At the early of 2016, Bengras Kopi Garut had to terminate his business relationship with Mr. Erwin. Then, two branches in Garut must be shut down. Thus, during 2016, Bengras Kopi Padang and Bengras Kopi BSI are only kept exist and sustaining their branches.

Mr. Erwin knew he could not handling business alone. Therefore, on July 2016, he formed team management for Bengras Kopi to develop $\mathrm{t} h$ e business system in Bengras Kopi. Then, this new team made an improvement to the business. The team opened a new branch in Soreang on September 16th, 2016. It followed by Bengras Kopi Telkom opened at the early of 2017. Then, at the end of 2018, Bengras Kopi Team starts to open new branches in Banjaran and Ciparay. However, currently, Bengras Kopi BSI has to temporarily vacuum because the team plans to form a new operation of this branch to Gede Bage.

This research tries to help Bengras Kopi's team to improve their franchise system through marketing mix. Marketing mix is not a scientific theory, but merely a conceptual framework that identifies the principal decision making by managers to configure their business offerings to suit customer's needs (Goi, 2009). According to Goi, the marketing mix concept has two important benefits. First, it is an important tool used to enable one to see a matter of trading off the benefits of one's competitive strengths against the benefits of others. The second benefit is to reveal another dimension of the marketing to allocate available resources among various demands and competitive device.

The major objective of this research is to assess $4 \mathrm{P}^{\prime} \mathrm{s}$ marketing mix practices that can be implemented in marketing strategy for small business coffee shops. The research question in this paper, what factors can help Bengras Kopi to improve marketing strategy to solve this problem?

\section{Methods}

This research uses quantitative methods that collected data through questionnaires. The type of this research is descriptive research that aims to describe the nature of something that is taking place at the time of research and checking causes of the particular symptom (Sekaran, 2011). The population is all customers of Bengras Kopi in Bandung and Padang. The sampling uses purposive sampling method that included non-probability sampling. The technique sampling uses accidental sampling with the total respondents is 113 customers. Furthermore, this research uses factor analysis to identify underlying factors that explain the correlations among a set of variables. It is a technique in the entire set of interdependent relationships is examined (Malhotra, 2004: 560). It is an exploratory technique applied to analyze the dependence of variables and simplify the relationship between several variables into a number of factors. Thus, the purpose of factor analysis is to reduce data and summarize several variables into particular number of factors.

Marketing mix is the main theory to analyze each variables in Bengras Kopi. The marketing mix is the set of controllable, tactical marketing tools that the firms blends to produce the response it wants in the target market (Kotler \& Armstrong, 2018: 55). In marketing mix analysis, this study analyze about product, price, place and promotion in customer perception and expectation. Perception is the process of selecting and interpreting sensations about what their feel about Bengras Kopi. Meanwhile, the expectation is what the customers beliefs about Bengras Kopi's performance as standards for their judgment. 


\section{Results and Discussion}

The objectives of this research is the customers who experiences visiting Bengras Kopi. This questionnaire held on June 2018. There are 113 customers selected and these data collected in June 2018 which spread in Bengras Kopi's branches in Telkom, Soreang, and Padang City. This research uses personally administered and online questionnaire. The total respondents answered by personally administered is 69 people. Then, 44 respondents answered questionnaire by online.

\section{Respondents Profile}

This research divided the respondent's profile into three characteristics; demographic, behavioral and visiting. In demographic, most of customers are men (78\%). Their aged dominated on 20-25 years $(67 \%)$ with occupation is undergraduate students (53\%). Mostly, the last education level is high school $(54 \%)$ and the income is $<\operatorname{Rp} 2.000 .000(53 \%)$.

Table 1 Demographic Characteristics of Respondents

b.

\begin{tabular}{|c|c|c|c|c|}
\hline Num & Categories & Demographic & $\begin{array}{l}\text { Total } \\
\text { Characteristics }\end{array}$ & Percentage \\
\hline \multirow[t]{2}{*}{1} & Gender & Men & 87 & $78 \%$ \\
\hline & & Women & 25 & $22 \%$ \\
\hline \multirow[t]{5}{*}{2} & Age & $15-20$ years & 7 & $6 \%$ \\
\hline & & $20-25$ years & 75 & $67 \%$ \\
\hline & & $25-30$ years & 24 & $21 \%$ \\
\hline & & 30-35 years & 4 & $4 \%$ \\
\hline & & $>35$ years & 2 & $2 \%$ \\
\hline \multirow[t]{9}{*}{3} & Occupation & Diploma & 2 & $2 \%$ \\
\hline & & Undergraduate & 60 & $53 \%$ \\
\hline & & Master & 3 & $3 \%$ \\
\hline & & Ph.D & 0 & $0 \%$ \\
\hline & & Entrepreneur & 11 & $10 \%$ \\
\hline & & Civil Servant & 1 & $1 \%$ \\
\hline & & Private & 23 & $20 \%$ \\
\hline & & Employee & & \\
\hline & & Others & 12 & $11 \%$ \\
\hline \multirow[t]{5}{*}{4} & Last Education & High School & 60 & $54 \%$ \\
\hline & & Diploma & 7 & $6 \%$ \\
\hline & & Undergraduate & 42 & $37 \%$ \\
\hline & & Master & 2 & $2 \%$ \\
\hline & & Others & 1 & $1 \%$ \\
\hline \multirow[t]{5}{*}{5} & Income & $<$ IDR 2.000 .000 & 56 & $53 \%$ \\
\hline & & IDR 2.000 .000 - IDR 4.000 .000 & 34 & $32 \%$ \\
\hline & & IDR 4.000.000 - IDR 6.000 .000 & 6 & $6 \%$ \\
\hline & & IDR 6.000 .000 - IDR 8.000 .000 & 3 & $3 \%$ \\
\hline & & $>$ IDR 8.000 .000 & 7 & $6 \%$ \\
\hline
\end{tabular}

According to the survey, most of the respondents frequently drinking coffee in coffee shop ( $74 \%)$. Drinking coffee is one of their lifestyles, they are usually drink it almost every day (53\%). The reason of drinking coffee for them is for refreshing (39\%) and their motive is chitchat or discussion $(64 \%)$. Lastly, they are usually spending around IDR 50.000 - IDR 100.000 (29\%) for drinking coffee. 
Table 2 Behavioral Characteristics of Respondents

\begin{tabular}{|c|c|c|c|c|}
\hline Numb. & $\begin{array}{c}\text { Behavioral } \\
\text { Characteristics }\end{array}$ & Categories & Total & Percentage \\
\hline \multirow[t]{5}{*}{1} & The Most Frequent & Home & 26 & $23 \%$ \\
\hline & Place for Drinking & Coffee Shop & 83 & $74 \%$ \\
\hline & Coffee & Office & 2 & $2 \%$ \\
\hline & & Restaurant & 0 & $0 \%$ \\
\hline & & Others & 1 & $1 \%$ \\
\hline \multirow[t]{5}{*}{2} & How Often & Almost Everyday & 59 & $53 \%$ \\
\hline & Drinking & Once A Week & 17 & $15 \%$ \\
\hline & Coffee & Once Per Two Weeks & 17 & $15 \%$ \\
\hline & & Once A Month & 5 & $4 \%$ \\
\hline & & Very Rarely & 14 & $13 \%$ \\
\hline \multirow[t]{5}{*}{3} & Reason for Drinking & Habit & 39 & $35 \%$ \\
\hline & Coffee & Relieve Drowsiness & 10 & $9 \%$ \\
\hline & & Refreshing & 44 & $39 \%$ \\
\hline & & Stamina Enhancer & 9 & $8 \%$ \\
\hline & & Others & 10 & $9 \%$ \\
\hline \multirow[t]{5}{*}{4} & Motivation Drinking & Seeking Atmosphere & 31 & $27 \%$ \\
\hline & $\begin{array}{l}\text { Coffee in Coffee } \\
\text { Shop }\end{array}$ & Doing Work & 3 & $3 \%$ \\
\hline & & Chitchat \& Discussion & 72 & $64 \%$ \\
\hline & & Reading Books & 1 & $1 \%$ \\
\hline & & Others & 6 & $5 \%$ \\
\hline \multirow[t]{5}{*}{5} & Expenses Drinking & $<$ IDR50.000 & 32 & $28 \%$ \\
\hline & Coffee for A Month & IDR 50.000 - IDR 100.000 & 33 & $29 \%$ \\
\hline & & IDR 100.000 - IDR150.000 & 25 & $22 \%$ \\
\hline & & IDR 150.000 - IDR250.000 & 14 & $13 \%$ \\
\hline & & $>$ IDR250.000 & 9 & $8 \%$ \\
\hline
\end{tabular}

Lastly, most of the respondents visting Bengras Kopi almost every day (44\%). They are getting know about this coffee shop from their relation $(72 \%)$, such as friends and families. Then, they are usually spending time during 2 - 3 hours with cost IDR5.000 - IDR15.000 (52\%).

Table 3 Bengras Kopi's Visiting Characteristics

\begin{tabular}{|c|c|c|c|c|}
\hline Numb. & $\begin{array}{c}\text { Bengras Kopi } \\
\text { Visiting Characteristics }\end{array}$ & Categories & Total & Percentage \\
\hline \multirow[t]{5}{*}{1} & \multirow[t]{5}{*}{ How Often Visiting } & Almost Everyday & 50 & $44 \%$ \\
\hline & & Once A Week & 16 & $14 \%$ \\
\hline & & Twice Per Month & 18 & $16 \%$ \\
\hline & & Once A Month & 9 & $8 \%$ \\
\hline & & Very Rarely & 20 & $18 \%$ \\
\hline \multirow[t]{5}{*}{2} & \multirow[t]{5}{*}{ Where Getting Know } & Relation & 82 & $72 \%$ \\
\hline & & Social Media & 2 & $2 \%$ \\
\hline & & Newspaper & 0 & $0 \%$ \\
\hline & & See Directly at Location & 29 & $26 \%$ \\
\hline & & Others & 0 & $0 \%$ \\
\hline
\end{tabular}


Table Cont...

\begin{tabular}{|c|c|c|c|c|}
\hline \multirow[t]{5}{*}{3} & \multirow[t]{5}{*}{ How Long Spending Time } & $<30$ Minutes & 9 & $8 \%$ \\
\hline & & 30 Minutes -1 Hours & 13 & $12 \%$ \\
\hline & & $1-2$ Hours & 23 & $21 \%$ \\
\hline & & $2-3$ Hours & 34 & $30 \%$ \\
\hline & & $>3$ Hours & 33 & $29 \%$ \\
\hline \multirow[t]{5}{*}{4} & \multirow[t]{5}{*}{ How Much Spending Cost } & IDR 5.000 - IDR 5.000 & 58 & $52 \%$ \\
\hline & & IDR 15.000-IDR 25.000 & 41 & $37 \%$ \\
\hline & & IDR 25.000 - IDR35.000 & 5 & $5 \%$ \\
\hline & & IDR35.000 - IDR45.000 & 5 & $5 \%$ \\
\hline & & $>$ IDR45.000 & 2 & $2 \%$ \\
\hline
\end{tabular}

\section{Product}

According the results from SPSS version 23, KMO value on customer perception is 0.819 and customer expectation is 0.871 (KMO value $>0.5)$ and both of the significance value of Barlett's Test of Sphericity is 0.000 (significance value $<0.5$ ). Therefore, the variables on customer's perception and expectation are acceptable. Furthermore, all value of Measure of Sampling Adequacy (MSA) are acceptable because the value of each variables is upper than 0.5 . Thus, these variables are sufficient to further analysis. Then, on customer's expectation, all variables in communalities can explain these relationships to factor because the values are upper than 0.5. However, on customer's perception, the value of menu variances, portion and availability stocks are lower than 0.5 . Therefore, these variables cannot explain its relationship to the product'sfactor.

Next, the value of all variables on component matrix are upper than 0.5. Thus, these variables have correlation with the factors. Lastly, the total eigenvalues of customer's perception are 4.102 and customer's expectation is 2.864. It means the value represents the total variance explained by factor on customer's perception and expectation are 4.102 and 2.684. Meanwhile, the percentage value of variance on customer's perception is 51.279 and customer's expectation is 61.387. It means, these factor are able to explain the variable diversity on $51.279 \%$ and $61.387 \%$.

Table 4 Factor Analysis of Product

\begin{tabular}{|c|c|c|c|c|c|c|c|}
\hline \multirow[b]{2}{*}{ Variables } & \multirow[b]{2}{*}{ KMO } & \multirow{2}{*}{$\begin{array}{c}\text { Barlett's } \\
\text { Test }\end{array}$} & \multirow{2}{*}{$\begin{array}{l}\text { Anti-Image } \\
\text { Correlation }\end{array}$} & \multirow[b]{2}{*}{ Communalities } & \multirow{2}{*}{$\begin{array}{c}\text { Component } \\
\text { Matrix }\end{array}$} & \multicolumn{2}{|c|}{ Initial Eigenvalues } \\
\hline & & & & & & Total & $\%$ of Variance \\
\hline \multicolumn{8}{|c|}{ Customer Perception } \\
\hline Coffee Aroma & \multirow{8}{*}{0,819} & \multirow{8}{*}{0,000} & 0,797 & 0,577 & 0,759 & \multirow{8}{*}{4,102} & \multirow{8}{*}{51,279} \\
\hline Quality Beverages & & & 0,749 & 0,673 & 0,820 & & \\
\hline Beverage Taste & & & 0,841 & 0,515 & 0,717 & & \\
\hline Beverage Served & & & 0,867 & 0,588 & 0,767 & & \\
\hline Hygienic & & & 0,812 & 0,537 & 0,733 & & \\
\hline Menu Variances & & & 0,740 & 0,362 & 0,602 & & \\
\hline Portion & & & 0,904 & 0,479 & 0,692 & & \\
\hline Availability Stocks & & & 0,905 & 0,373 & 0,610 & & \\
\hline \multicolumn{8}{|c|}{ Customer Expectation } \\
\hline Coffee Aroma & \multirow{9}{*}{0,871} & \multirow{9}{*}{0,000} & 0,849 & 0,674 & 0,821 & \multirow{9}{*}{2,864} & \multirow{9}{*}{61,387} \\
\hline Table count... & & & & & & & \\
\hline Quality Beverages & & & 0,824 & 0,689 & 0,830 & & \\
\hline Beverage Taste & & & 0,888 & 0,714 & 0,845 & & \\
\hline Beverage Served & & & 0,877 & 0,612 & 0,782 & & \\
\hline Hygienic & & & 0,853 & 0,556 & 0,746 & & \\
\hline Menu Variances & & & 0,883 & 0,531 & 0,729 & & \\
\hline Portion & & & 0,899 & 0,618 & 0,786 & & \\
\hline Availability Stocks & & & 0,919 & 0,523 & 0,724 & & \\
\hline
\end{tabular}




\section{Price}

According the results, $\mathrm{KMO}$ value on customer perception is 0.826 and customer expectation is 0.796 (KMO value $>0.5$ ) and both of the significance value of Barlett's Test of Sphericity is 0.000 (significance value $<0.5$ ). Therefore, the variables on customer's perception and expectation are acceptable. Furthermore, all value of Measure of Sampling Adequacy (MSA) are acceptable because the value of each variables is upper than 0.5. Thus, these variables are sufficient to further analysis. Then, on customer's expectation, all variables in communalities can explain these relationships to factor because the values are upper than 0.5 . However, on customer's perception, the value of list prices is lower than 0.5. Therefore, this variable cannot explain its relationship to the price's factor.

Next, the value of all variables on component matrix are upper than 0.5 . Thus, these variables have correlation with the factors. Lastly, the total eigenvalues of customer's perception are 3.149 and customer's expectation is 1.652. It means the value represents the total variance explained by factor on customer's perception and expectation are 3.149 and 1.652. Meanwhile, the percentage value of variance on customer's perception is 62.975 and customer's expectation is 64.941. It means, these factors are able to explain the variable diversity on $62.975 \%$ and $64.941 \%$.

Table 5 Factor Analysis of Price

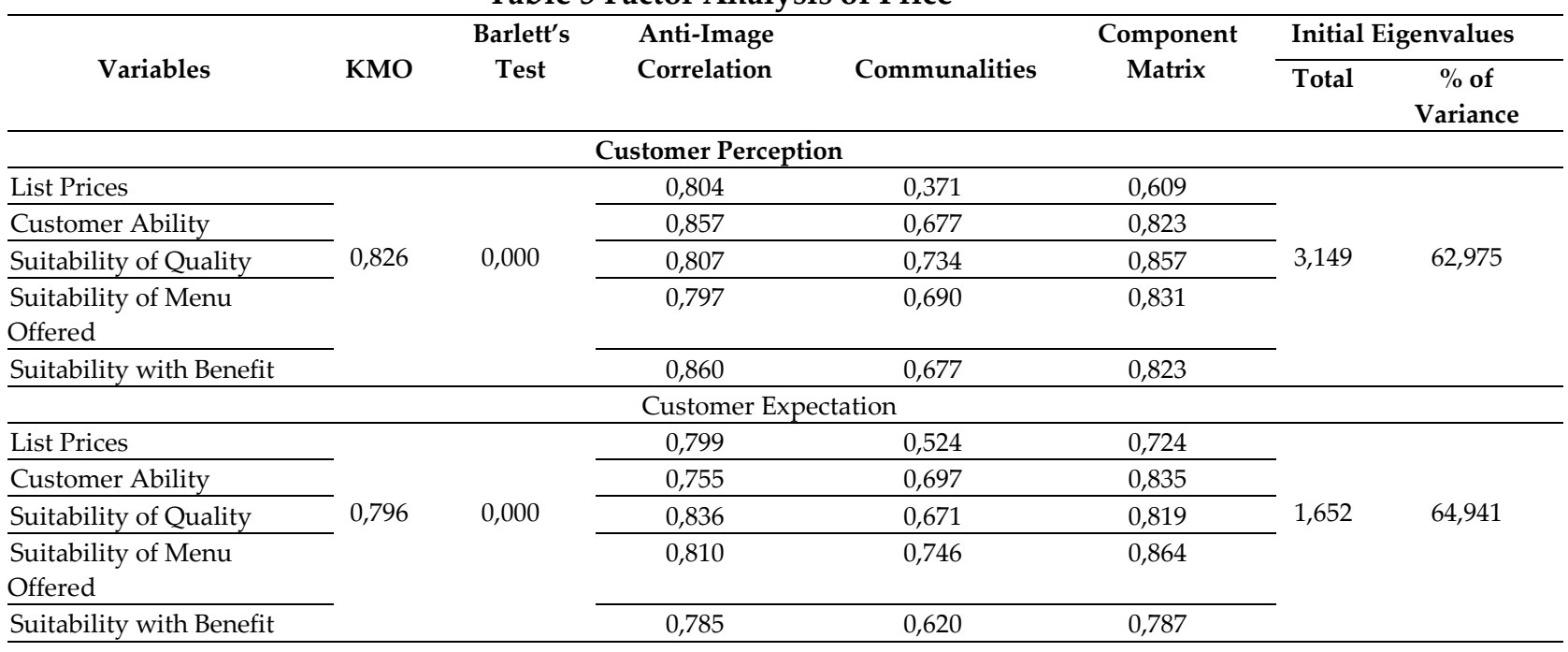

Place

According the results, $\mathrm{KMO}$ value on customer perception is 0.875 and customer expectation is 0.802 (KMO value $>0.5$ ) and both of the significance value of Barlett's Test of Sphericity is 0.000 (significance value $<0.5$ ). Therefore, the variables on customer's perception and expectation are acceptable. Furthermore, all value of Measure of Sampling Adequacy (MSA) are acceptable because the value of each variables are upper than 0.5. Thus, these variables are sufficient to further analysis. Then, all variables in communalities can explain these relationship to factor because the values are upper than 0.5 .

On component matrix, there are three factors divided on this analysis. However, only factor 1 is acceptable because the value of all these variables are upper than 0.5. Meanwhile, most of the variables on factor 2 and 3 are lower than 0.5. Lastly, the total eigenvalues of customer's perception are $7.611,2.080$, and 1.025 . Thus, the total percentage value of variances is $66.974 \%(47.569+12.999+$ 6.406). Meanwhile, the total eigenvalues of customer's expectation are 5.263, 1,068 and 0,615. The percentage value of variance on customer's expectation is $71.689 \%(54.320+11.023+6.346)$. 
Table 6 Factor Analysis of Place

\begin{tabular}{|c|c|c|c|c|c|c|c|c|c|}
\hline \multirow[b]{2}{*}{ Variables } & \multirow[b]{2}{*}{ KMO } & \multirow{2}{*}{$\begin{array}{c}\text { Barlett's } \\
\text { Test }\end{array}$} & \multirow{2}{*}{$\begin{array}{l}\text { Anti-Image } \\
\text { Correlation }\end{array}$} & \multirow{2}{*}{$\begin{array}{c}\text { Communal } \\
\text { ities }\end{array}$} & \multicolumn{3}{|c|}{ Component Matrix } & \multicolumn{2}{|c|}{ Initial Eigenvalues } \\
\hline & & & & & 1 & 2 & 3 & Total & $\begin{array}{c}\% \text { of } \\
\text { Variance }\end{array}$ \\
\hline \multicolumn{10}{|l|}{ Customer Perception } \\
\hline Strategic Location & \multirow{10}{*}{$-0,875$} & \multirow{10}{*}{0,000} & 0,814 & 0,636 & 0,623 & $-0,485$ & 0,112 & 7,611 & 47,569 \\
\hline Easily Access & & & 0,797 & 0,788 & 0,592 & $-0,650$ & 0,121 & 2,080 & 12,999 \\
\hline Proximity Crowdness & & & 0,916 & 0,743 & 0,635 & $-0,406$ & 0,417 & 1,025 & 6,406 \\
\hline Secure Place & & & 0,837 & 0,698 & 0,713 & $-0,318$ & 0,282 & & \\
\hline Comfortable Atmosphere & & & 0,924 & 0,671 & 0,777 & $-0,260$ & $-0,016$ & & \\
\hline Cleanliness & & & 0,895 & 0,539 & 0,667 & $-0,183$ & $-0,247$ & & \\
\hline Wide Space & & & 0,844 & 0,507 & 0,501 & 0,479 & 0,164 & & \\
\hline Tidy Layout & & & 0,930 & 0,648 & 0,759 & 0,092 & $-0,252$ & & \\
\hline Decoration & & & 0,915 & 0,641 & 0,719 & 0,346 & $-0,065$ & & \\
\hline Lightning & & & 0,893 & 0,574 & 0,754 & 0,044 & 0,060 & & \\
\hline $\begin{array}{l}\text { Completeness of Tables \& } \\
\text { Chairs }\end{array}$ & & & 0,895 & 0,615 & 0,665 & 0,353 & $-0,219$ & & \\
\hline $\begin{array}{l}\text { Cleanliness of Tables \& } \\
\text { Chairs }\end{array}$ & & & 0,881 & 0,756 & 0,811 & $-0,095$ & $-0,299$ & & \\
\hline Completeness of Equipment & & & 0,896 & 0,699 & 0,775 & 0,164 & $-0,268$ & & \\
\hline Cleanliness of Equipment & & & 0,894 & 0,668 & 0,783 & 0,018 & $-0,234$ & & \\
\hline Wide Parking & & & 0,794 & 0,812 & 0,577 & 0,509 & 0,470 & & \\
\hline Tidy Parking & & & 0,823 & 0,730 & 0,596 & 0,524 & 0,316 & & \\
\hline \multicolumn{10}{|l|}{ Customer Expectation } \\
\hline Strategic Location & 0,802 & 0,000 & 0,818 & 0,644 & 0,680 & $-0,427$ & - & 5,263 & 54,320 \\
\hline Easily Access & & & 0,851 & 0,785 & 0,728 & $-0,505$ & - & 1,068 & 11,023 \\
\hline Proximity Crowdness & & & 0,938 & 0,709 & 0,750 & $-0,382$ & - & 0,615 & 6,346 \\
\hline Secure Place & & & 0,862 & 0,702 & 0,765 & $-0,342$ & - & & \\
\hline Comfortable Atmosphere & & & 0,859 & 0,603 & 0,738 & $-0,239$ & - & & \\
\hline Cleanliness & & & 0,957 & 0,747 & 0,821 & $-0,270$ & - & & \\
\hline Wide Space & & & 0,897 & 0,625 & 0,663 & 0,431 & - & & \\
\hline \multicolumn{10}{|l|}{ Table count... } \\
\hline Tidy Layout & & & 0,917 & 0,647 & 0,803 & 0,040 & - & & \\
\hline Decoration & & & 0,840 & 0,581 & 0,705 & 0,289 & - & & \\
\hline Lightning & & & 0,911 & 0,552 & 0,694 & 0,265 & - & & \\
\hline $\begin{array}{l}\text { Completeness of Tables \& } \\
\text { Chairs }\end{array}$ & & & 0,891 & 0,647 & 0,703 & 0,392 & - & & \\
\hline $\begin{array}{l}\text { Cleanliness of Tables \& } \\
\text { Chairs }\end{array}$ & & & 0,916 & 0,696 & 0,809 & $-0,206$ & - & & \\
\hline$\overline{\text { Completeness of Equipment }}$ & & & 0,868 & 0,599 & 0,752 & 0,181 & - & & \\
\hline Cleanliness of Equipment & & & 0,823 & 0,598 & 0,764 & 0,121 & - & & \\
\hline Wide Parking & & & 0,811 & 0,650 & 0,693 & 0,412 & - & & \\
\hline Tidy Parking & & & 0,853 & 0,655 & 0,711 & 0,388 & - & & \\
\hline
\end{tabular}

\section{Promotion}

According the results, $\mathrm{KMO}$ value on customer perception is 0.864 and customer expectation is 0.900 (KMO value > 0.5) and both of the significance value of Barlett's Test of Sphericity is 0.000 (significance value $<0.5$ ). Therefore, the variables on customer's perception and expectation are acceptable. Furthermore, all value of Measure of Sampling Adequacy (MSA) are acceptable because the value of each variables are upper than 0.5. Thus, these variables are sufficient to further analysis. Then, on customer's expectation, all variables in communalities can explain these relationship to factor because the values are upper than 0.5. However, on customer's perception, the value of Bengras Kopi's board are lower than 0.5 . Therefore, this variable cannot explain its relationship to the promotion's factor.

Next, the value of all variables on component matrix are upper than 0.5 . Thus, these variables have correlation with the factors. Lastly, the total eigenvalues of customer's perception is 4.729 and customer's expectation is 3.556. It means the value represents the total variance explained by factor on customer's perception and expectation are 4.729 and 3.556. Meanwhile, the percentage value of 
variance on customer's perception is 59.114 and customer's expectation is 63.502. It means, these factor are able to explain the variable diversity on $59.114 \%$ and $63.502 \%$.

Table 7 Factor Analysis of Promotion

\begin{tabular}{|c|c|c|c|c|c|c|c|}
\hline \multirow[b]{2}{*}{ Variables } & \multirow[b]{2}{*}{ KMO } & \multirow{2}{*}{$\begin{array}{c}\text { Barlett's } \\
\text { Test }\end{array}$} & \multirow{2}{*}{$\begin{array}{l}\text { Anti-Image } \\
\text { Correlation }\end{array}$} & \multirow{2}{*}{$\begin{array}{c}\text { Commun } \\
\text { al ities }\end{array}$} & \multirow{2}{*}{$\begin{array}{c}\text { Component } \\
\text { Matrix }\end{array}$} & \multicolumn{2}{|c|}{ Initial Eigenvalues } \\
\hline & & & & & & Total & $\begin{array}{c}\% \text { of } \\
\text { Variance }\end{array}$ \\
\hline \multicolumn{8}{|l|}{ Customer Perception } \\
\hline Bengras Kopi's & \multirow{9}{*}{0,864} & \multirow{9}{*}{0,000} & 0,907 & 346 & 0,588 & \multirow{9}{*}{4,729} & \multirow{9}{*}{59,114} \\
\hline Board & & & & & & & \\
\hline Photo Content on Instagram & & & 0,914 & 0,582 & 0,763 & & \\
\hline Promo Attractiveness & & & 0,878 & 0,652 & 0,808 & & \\
\hline Special Offered & & & 0,857 & 0,603 & 0,777 & & \\
\hline Free Gift & & & 0,868 & 0,634 & 0,796 & & \\
\hline Easily Access for Information & & & 0,892 & 0,672 & 0,820 & & \\
\hline Actively Participate on Events & & & 0,838 & 0,659 & 0,812 & & \\
\hline Demo Attractiveness & & & 0,789 & 0,581 & 0,762 & & \\
\hline \multicolumn{8}{|l|}{ Customer Expectation } \\
\hline Bengras Kopi's Board & \multirow{8}{*}{0,900} & \multirow{8}{*}{0,000} & 0,892 & 0,656 & 0,810 & \multirow{8}{*}{3,556} & \multirow{8}{*}{63,502} \\
\hline Photo Content on Instagram & & & 0,882 & 0,714 & 0,845 & & \\
\hline Promo Attractiveness & & & 0,895 & 0,668 & 0,817 & & \\
\hline Special Offered & & & 0,885 & 0,621 & 0,788 & & \\
\hline Free Gift & & & 0,885 & 0,580 & 0,762 & & \\
\hline Easily Access for Information & & & 0,909 & 0,746 & 0,864 & & \\
\hline Actively Participate on Events & & & 0,914 & 0,586 & 0,765 & & \\
\hline Demo Attractiveness & & & 0,956 & 0,523 & 0,723 & & \\
\hline
\end{tabular}

\section{Conclusions}

Based on the results of factor analysis, the marketing mix are the important tools for Bengras Kopi to improve marketing strategy. It is found most of all variables are acceptable and good correlation to the factors. On customer's perception, Place is the highest factor with the KMO's score is 0.875 . Meanwhile on customer's expectation, Promotion is the highest factor with the KMO's score is 0.900 . In conclusion, these variables can be uses as the measurement scores for indicators in marketing plan.

This research only limited 4P's factors (Product, Price, Place and Promotion) with Bengras Kopi as the main object. Every coffee shop has different strategies. Thus, further research can add Service as one of the factors. Moreover, this research can be more explorative for any coffee shops in Bandung or Padang based on customer's perspective.

\section{References}

BBC News, (2018), Coffee: Who grows, drinks and pays the most? April 13 at https://www.bbc.com/news/business-43742686

Goi, C. L. (2009). A Review of Marketing Mix: 4Ps or More? International Journal of Marketing Studies, Vol. 1(1): 2-15.

Indonesia Investments, (2017), Domestic Coffee Production., November 13 at https://www.indonesiainvestments.com/business/commodities/coffee/item186?

Kotler, Philip and Amstrong, Gary. (2018). Principles of Marketing. 17th Edition. England: Pearson. Malhotra, N. (2014), Marketing Research: An Applied Orientation. New Jersey: Pearson Education. Sekaran, U. (2011). Research Methods for Business. Jakarta: Salemba Empat.

Tempo.Co. (2017). Indonesia Dominates Global Retail Coffee Market., March 06 at https://en.tempo.co/read/news/2017/03/06/056853210/Indonesia-DominatesGlobal-Retail- Coffee-Market 